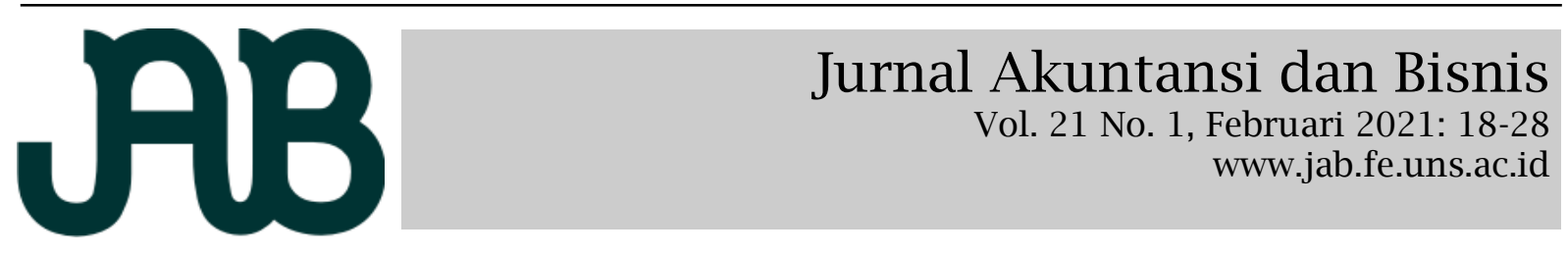

\title{
ACCOUNTING FOR STARTUP: AS SCARY AS FREDDY
}

\section{YUDHA ARYO SUDIBYO (yudha.sudibyo@unsoed.ac.id) NOVITA PUSPASARI}

Accounting Study Program, Faculty of Economics and Business, Universitas Jenderal Soedirman, Indonesia

\begin{abstract}
A B S T R A C T
Indonesia has enormous numbers of startup companies which grow rapidly in the past four years. However, many startups fail in the first year due to their lack of business sustainability. The problem for most startups is measurement. To measure its growth and efficiency, startup companies need accounting. This study aims to explore and gain an in-depth understanding from the view of startup companies on accounting. With a qualitative approach, this study used the ZMET (Zaltman Metaphor Elicitation Technique) method to dig information from seven startup companies as research participants. Using ZMET's projective techniques through image metaphors, the study has identified thirteen important constructs which describe a mental model of startup companies toward accounting. Connections among constructs are described in the consensus map, which explains three main themes of this study's findings: mental block of accounting, accounting as a tool, and ultimate startup goal. This study has theoretical contributions, practical contributions, and methodological contributions.

Keywords: startup, accounting, ZMET, and qualitative.

Indonesia memiliki sejumlah besar perusahaan startup yang tumbuh pesat dalam empat tahun terakhir. Namun, banyak startup gagal pada tahun pertama karena kurangnya keberlanjutan bisnis. Masalah yang banyak dihadapi oleh startup adalah pengukuran. Akuntansi diperlukan oleh startup untuk mengukur pertumbuhan dan efisiensinya. Penelitian ini bertujuan untuk mengeksplorasi dan memperoleh pemahaman mendalam dari perusahaan startup mengenai akuntansi. Studi ini menggunakan pendekatan kualitatif, metode ZMET (Zaltman Metaphor Elicitation Technique) digunakan untuk menggali informasi dari tujuh perusahaan startup yang dijadikan partisipan. Proyeksi ZMET mengidentifikasi tiga belas konstruk penting yang menggambarkan model mental perusahaan startup terhadap akuntansi. Hubungan antar konstruk digambarkan melalui consensus map yang menjelaskan tiga temuan penting yaitu mental block akuntansi, akuntansi sebagai alat dan tujuan akhir startup. Penelitian ini mempunyai kontribusi terhadap teori, praktik, dan metodologi.
\end{abstract}

Kata kunci: Startup, Akuntansi, ZMET, dan kualitatif

\section{INTRODUCTION}

The growth of startups in Indonesia has been very rapid in recent years. According to data from the Startup Ranking (2018), Indonesia ranks fourth in countries with the most startups in the world. Indonesia has around 1,705 startups, under the United States (28,794 startups), India (4,713 startups), and the UK (2,971 startups). In the Southeast Asia region, there are currently seven unicorn startups; unicorn is the status given to a startup with a valuation of more than US $\$ 1$ billion. There are four startups, namely GoJek, Tokopedia, Traveloka, and Bukalapak from Indonesia. The other three are Sea Ltd and Grab from Singapore and Revolution Precrafted from the Philippines. However, many startup businesses have been created, and many others have collapsed (Groenewegen \& De Langen, 2012). According to Ries (2011), the main problem facing startups is business continuity. As a business organization always required to innovate, startups are often trapped in the paradigm of only producing products that make goods, money and serve consumers. Startup companies sometimes forget to learn to do a sustainable business. Sustainable business can be built through an ade- 
quate accounting process to measure progress, set targets, and prioritize work.

Accounting has long been the key to success for large companies. Nevertheless, the accounting role for the startup is still questionable. Startups are often treated like MSMEs, including financial records, whereas the characteristics between startups and MSMEs are very different. For example, MSMEs classify assets and turnover, while startups cannot only be seen from assets and turnover. Technology adoption for MSMEs is still limited, while startups have high technology. In terms of revenue, MSME revenue is usually from the sale of goods/services, while startups often through fee-based revenue. With these different characteristics, startups need a different type of accounting.

Ries (2011), Groenewegen \& De Langen (2012), and Soto (2015) stated that a new type of measurement is needed for startups. Accounting Innovation is one branch of accounting that is considered appropriate for startups (Ries, 2011). Unfortunately, accounting innovation has not been implemented much at startup. Basic accounting has not also been implemented well by startup companies. What are the perceptions of startup companies against accounting? How do they use accounting in their daily business processes? How accounting contributes to developing a startup business? These questions cannot be answered with quantitative research. Exploration on this matter is important because startups are currently growing rapidly in Indonesia. If it is not supported by appropriate accounting, the startup can experience failure in terms of sustainability.

This research aims to explore and gain an in-depth understanding of the perceptions of startup companies towards accounting. Therefore, this research applies a qualitative interpretive approach using the ZMET (Zaltman Metaphor Elicitation Technique) method in gathering information. The research question answered in this research is: how is the mental model of the startup actors when dealing with accounting.

ZMET is a variation in interviews as a method of collecting data by utilizing projective techniques. Projective techniques are used to overcome collecting data with traditional surveys or interviews that rely on direct questions. Participants often have difficulty responding to such questions to give their views on something (Coulter, Zaltman \& Coulter, 2001; Khoo-Lattimore, Thyne \& Robertson, 2009). Gerald Zaltman first developed ZMET. Zaltman (1995) argues that many things occur in the mind, but often a person does not realize it. Most things that affect words and actions occur at an unconscious level. It takes a technique to get the hidden knowledge to get things that people do not know or want. Because of this, he created ZMET. In this method, images play an important role as a medium to bring up metaphors. Images are stimuli during in-depth interviews to explore and explore participants' thoughts and feelings. The use of these images is based on the findings of cognitive psychology that most information reaches the human brain through a visual system, which many of its communications are nonverbal. Humans think in images (images), not words (Coulter et al., 2001; Zaltman, 1996). The advantage of the ZMET method is that it can counter the depth deficit compared to the traditional qualitative "words only" research approach. This method could be applied to numerous contexts where the research attempts to expose the subconscious meanings people attach to a phenomenon (Hancock \& Foster, 2019).

Puspasari, Herwiyanti \& Pinasti (2021) found that ZMET can be a powerful tool in exploring one's perception regarding a specific issue. Puspasari, et al. (2021) observed SME's perceptions on the tax imposed on their business. The findings were somewhat interesting since most SME participants perceived that the government was not fair regarding tax treatment compared to larger businesses. The depth of the findings can be gained using ZMET. Therefore, ZMET is used in this study to obtain a deep understanding of startup's perception of accounting.

The results of this research provide several contributions; theoretical 
contributions, practical contributions, and methodological contributions. Concerning theoretical contribution, this research provides an in-depth explanation of how startup companies perceive accounting. This explanation does not yet exist in previous studies. Therefore, this research will be the basis for developing research on accounting for startups in the future.

Concerning practical contribution, this research will encourage efforts of accounting development to be more applied and useful for startup companies. This improvement can be made from the regulator and startup company side. Regarding the methodological contribution, research that applies the ZMET method in accounting is still very limited. As far as the researcher's knowledge, there has been no previous research that applied the ZMET method to explore the perceptions of startup companies towards accounting. This research can be a reference for further research on the application of the ZMET method in accounting.

The next part of this paper is organized as follows. The second part describes the literature review relating to changes in the economic model of the owning economy to the collaborative economy, startup, and accounting for startups. The third one explains the research methods applied. Presents the results of the research and discussion is the fourth part. The fifth section contains conclusions, implications, limitations, and future research opportunities.

\section{LITERATURE REVIEW}

\section{From Owning Economy to Sharing Economy/Collaborative Economy}

Kasali (2018) stated that we move from the owning economy model towards sharing economy model today. The first model implies individual business ownership; thus, all things must be carried out independently. Various investments are borne by themselves and will be received by themselves. The second model, sharing economy, works by collaborating on the idle assets of many people. With such a basic pattern, the second model is also often called a collaborative economy.
Today the second model develops in many sectors, ranging from retail, transportation, rental services, and others. The latter model, according to Kasali (2018), is more efficient than the first. With a nonconventional business model plus platform -based technology, the second model makes many connected parties enjoy better economic cakes. The keywords for the latter model are: sharing assets and sharing risks.

Nowadays, if you want to travel by motorbike or car, you do not need to own a motorbike or car first. You can use Grab or Gojek. The last economic activity does not require you to have assets; first, economic activities can be done by sharing resources. On Gojek, car asset owners are drivers, platform owners are Gojek, and consumers are money owners who can afford Gojek's services. According to Kasali (2018), the basis of sharing economy/collaborative economy is sharing resources, sharing the economic role of each resource owned. Therefore, there is an orchestration of collaboration with different roles. This approach has become the new way of carrying out economic activities.

\section{Startup and Lean Startup Approach}

According to Ries (2011), the vision of a startup is to create profitable businesses that can change the world. The goal of a startup is to find out exactly what should be made of goods and or services that consumers want, thus make them want to pay in the shortest possible time. Meanwhile, lean startup is a new way to develop innovative products with pressure on rapid trial and error, consumer interest, big vision, and exorbitant ambitions. Lean startup is a strategy to minimize failure experienced by many startups. According to Ries (2011), the five principles in the lean startup are: entrepreneurs are everywhere, management is the key to entrepreneurship, validated learning, buildmeasure-learn, and innovation accounting. We can conclude from those five principles that a startup needs innovation and the right measurement to grow.

Based on Groenewegen \& De Langen (2012), two distinct groups of critical 
success factors (CSF) were found for a startup:organizational and entrepreneurial. This opinion complies with De Mel, McKenzie \& Woodruff (2009), who asks if the innovative power of a company is determined by the innovative power of the organization or the innovative power of the owners. On an organizational level, the success is influenced by a thorough business plan, a clear strategy/mark analysis/competitor analyses, and aggressive competitor strategy the usage of innovation as a business idea, being a member of a formal network having an advisory board active marketing. On the entrepreneurial level, these factors are the need for achievement, having the locus of control, the willingness to take risks, number of years experience, experience as an entrepreneur, industry-specific experience, management experience, and a relevant social network (Brem, 2008; Nandram \& Boemans, 2001; Rauch, 2000).

\section{Accounting for Startup}

Based on Ries (2011) in build-measurelearn, the startup needs to measure its progress. The progress must be measured; therefore, the growth and the efficiency will be known. The results will also provide an objective analysis of how this startup operates and whether it should stop or continue moving. In innovation accounting, the first step is startup has to have a minimum viable product (MVP) as a baseline. With MVP, a startup will modify its strategy and measure which one is working and which one is not. Accounting has to be implemented to control every aspect of the business; therefore, it contributes greatly to its success (Ries, 2011). According to Croll \& Yoskovitz (2013), the fundamental accounting process starts the minute you develop and launch an MVP because every interaction between customer and MVP results will provide data that can be used to analyze.

McClure (2008) suggests four measurement types analyze startup data: qualitative, quantitative, comparative, and competitive. Qualitative measurement focus on a small group of users through usability testing. By monitoring this group of users, a startup can optimize the service based on the problems seen during the test. Quantitative measures how users engage with the service provided by the startup, for example, in terms of conversion, conversion percentage, and traffic. Comparative used to compare users in two or more different situations. Most of the time, comparative measurement uses cohort analysis, segmentation, and A/B tests. This comparison will give data on which situation is preferable or most effective (Croll \& Yoskovitz, 2013). Comparisons can be used through channels, keyword traffic, customer satisfaction, demographics, etc. Competitive measurement means tracking competitors and starting to compare activities.

In Indonesia, startup reporting usually uses the accounting standards of Entities without Public Accountability (ETAP). The Indonesia Stock Exchange (IDX) provides some special treatment for startup companies that want to be listed on the IDX. IDX called it "General PSAK". Startup companies may not list their board of directors, and there is no obligation to display the income statement (may lose), especially for startup companies, which are seen not in the bottom line but the future. Startup companies will also get a special code different from the code that has existed so far.

\section{RESEARCH METHODS}

\section{ZMET Technique in Data Collection and Analysis}

This study uses a qualitative approach with ZMET (Zaltman Metaphor Elicitation Technique) method to collect data and information. ZMET is one of the techniques in qualitative research which insights from the mind science to open the unconscious mind to understand beliefs, behaviors, and decisions that are made by someone using imagery media. The main goal of ZMET is to gain an in-depth understanding of the participants' views on something (Coulter et al., 2001; Khoo-Lattimore et al., 2009). This research aims to explore and gain a deep understanding of startup companies' views (mindset) against accounting. 
Therefore, ZMET, as a projective technique, is very appropriate for data collection and analysis in this study.

Before the ZMET interview was conducted, participants were asked to look for eight to ten images expressing their thoughts and feelings about startup accounting. Participants in this study are startup business actors. Participants can choose images from various sources, including from the internet. In this study, all participants used the internet to search for images. Participants were given a week to search images before the ZMET interview was conducted.

At the individual interview stage, the data collection procedure carried out in this study refers to the ZMET procedure as stated in Coulter (2006); Zaltman (1997); Zaltman (1996) as follows: (a)Storytelling: Participants are asked to describe the contents of each picture (one by one) based on their thoughts and feelings. The researcher conducts probing when the participant tells a story. (B) Missed images: The participant was asked if there were important ideas he wanted to express but he was unable to find relevant images. (c) Sorting task: Participants were asked to sort images into meaningful sequences . (d) Construct elicitation: While listening to the participants stories about the pictures, the researchers recorded any important words that describe the participants' experiences. The important words are the constructs that are raised. (e) The most representative picture: Participants are asked to indicate which image best represents their view and explain the reason. (f)Opposite images: Participants are asked to indicate which image is the opposite of the most representative image for them (stage 5). The opposite image can be sourced from existing images, can also be images that don't exist. (g) Sensory images: Participants are asked to describe what taste, smell, texture, sound, and color are associated with accounting. (h) Mental map: Participants were asked to create a map or causal model based on the constructs that appeared in the previous stages. (i) Summary image: Participants were asked to create collages (summaries) of images that expressed their views on accounting.

The last stage is to build a consensus map (consensus map) of all study participants. The researcher creates a causal map or model that shows the most important constructs of all participants. The constructs that emerged from all participants were then reduced (grouped/ categorized) by determining the main themes based on the results of the individual ZMET interviews conducted. This consensus map in the form of a diagrammatic scheme is the main outcome, which describes the views of startup companies towards accounting.

\section{Research Participants}

Participants in this study were business startups consisting of founders and cofounders of startup companies. Participants involved in this study were seven people consisting of three founders and four co-founders' of startups. Adequacy of the number of participants is based on Zaltman's (1997) statement that ZMET interviews of 4-5 people provide approximately $90 \%$ of the main information extracted from all interviews. Previous research also shows that the number of constructs identified with ZMET will not increase if the number of participants is increased (Danilet \& Bobalca, 2017).

Two founders have an educational background in Information Technology, one founder has a background in English Literature. The educational background of co-founders varies from Law, Communication, Information Technology, to State Administration. Most of the startup companies are based in Purwokerto, Central Java, while only one startup company of the participants is based in Yogyakarta. Six participants were male and one participant was female, and their ages ranging from 21-28 years old. Their startups have been established for one to four years (early stage of development).

\section{ANALYSIS AND DISCUSSION}

Identify Constructs Emerged

The results of the ZMET interview on each startup participant produced data and 
Table 1.

Examples of Image and Construct Metaphors Appeared by Participants

\begin{tabular}{|c|c|c|}
\hline Images & $\begin{array}{c}\text { Construct } \\
\text { emerged }\end{array}$ & Story telling of Images \\
\hline & Confusing & $\begin{array}{l}\text { "I think accounting like tangled } \\
\text { threads in my head. I tried to } \\
\text { decipher it, sorting out what was } \\
\text { first done regarding accounting. } \\
\text { But still bundle! "!" }\end{array}$ \\
\hline
\end{tabular}

Source: https://www.freepik.com

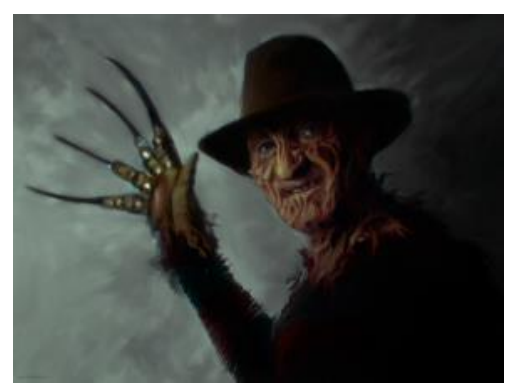

Source: https://flickr.com/

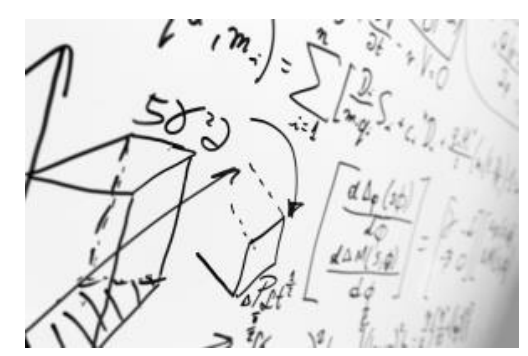

Source: https://freepik.com/

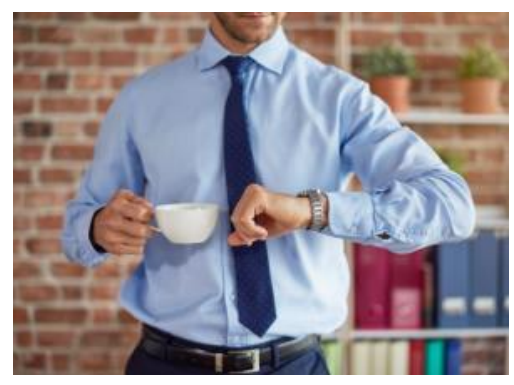

Source: https://www.freepik.com/

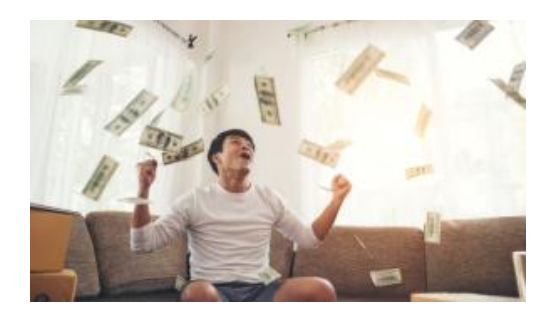

Source: https://www.freepik.com
Complicated

Well Managed

"The impression is like when you meet Freddy Krueger (from Nightmare on Elm Street). It is scary, pushing you to the corner until you do not have space to move and room to breathe. And with its knife fingers, ready to chop you into pieces if you're not obey him"

"I don't get accounting. I have tried, trust me. But the more I try, the more I get confused. Pardon, is accounting the real solution?, I don't think so. If this (accounting) a tool that tend to help my business, then why it makes me dizzy?"

"In order to build a sustainable business, I realize that I need accounting. It helps me a lot to manage my business. This system enable me to plan better"

"Well, we all (startup companies) wants to be a Unicorn like Gojek. We want to gain more, and give impact more. Thus we need accounting in developing our business. It's our job (founder and co-founders) to innovate. Accounting job is to give us more yield" 
information which became the basis for identifying important constructs. Information was obtained from the pictures selected by participants before the ZMET process, descriptions of the images in the storytelling stage, missed images identification, image classification, most representative images, opposite images, mental map from each participant, and collage images from each participant.

In the storytelling stage, participants choose images that show a metaphor for their views on accounting. The metaphor in the picture contains important constructs that participants raise. Some examples of images chosen as metaphors by participants and important constructs in them are shown in Table 1.

In the sensory image stage, several participant statements confirm several constructs that appear. The "scary" and "uncomfortable" constructs appeared in five participants. For example, when asked to explain smells, participant 1 said "like a dementor" whose presence sucks happiness. The "wealth" and "growth" constructs appeared in three participants because they explained that accounting smelled like new money if kissed. Participant 4 even identified the sound heard from accounting words such as "sports car exhaust" because it feels that accounting will make them rich.

The collage of images compiled by each participant at the final stage of an individual ZMET interview explains the links between constructs that appeared. Participant number 1 considers accounting confusing and scary, as seen in the first group of images. These "confusing" and "scary" constructs have been repeatedly stated by other participants, like participant 2, who considered accounting as scary as the character of Freddy Krueger in the horror film Nightmare on Elm Street. Freddy is famous for its metal-clawed brown leather glove only on his right hand. "It's scary like Freddie. His metal-clawed leather seems to insist that you (startup) don't comply with accounting rules, I will scratch you".

In the second group of images, it is known that even though participant number 1 thinks negatively about accounting, he believes that accounting is a "tool" that will make him "wealthy." Accounting as a tool is illustrated in the second group of pictures showing people doing calculations and a ladder. Images of people doing calculations show that accounting makes business startups well mâhaged and transparent. The ladder figure shows that accounting will bring startup companies to prosperity. There are three images in the third group of images: a unicorn, growth chart, and angel investor. Participant number 1 believes that startup companies can develop into a unicorn with good accounting records, capturing growth precisely and attracting angel investors.

Based on the results of interviews with the ZMET method for the seven startup companies participants, twelve important constructs were obtained, namely: (1) confusing, (2) complicated, (3) scary, (4) uncomfortable, (5) lack of knowledge in accounting, (6 ) lack of accounting implementation, (7) good governance, (8) transparency, (9) well managed (10) responsibility to investors, (11) growth, (12) sustainability, (13) wealth. These thirteen important contracts will form a consensus map.

\section{Consensus Map}

The thirteen important contracts that emerged in the ZMET process are presented in the consensus map in figure 1. In the ZMET method, consensus maps are one of the most important outcomes. Zaltman (1995) and Coulter et al (2001) stated that direct and indirect connections between constructs represent logical reasoning, showing how a thought raises other thoughts. Different symbols are used to represent different types of constructs. Circle symbols indicate the originator constructs, rectangular symbols indicate destination constructs, and parallelogram symbols indicate connector constructs. The relationship between constructs is indicated by unidirectional or bi-directional arrows (Danilet \& Bobalca, 2017). The consensus map from this study uses different symbols for different types of constructs. Referring to Danilet \& Bobalca's 
(2017) research, circle symbols indicate the originator constructs, rectangular symbols indicate destination constructs, and parallelogram symbols indicate connector constructs. While arrows indicate the relationship between constructs.

The originator construct identified in this study was: lack of accounting knowledge. Participants see this construct as the cause of the emergence of other constructs. Because of a lack of accounting knowledge, startup companies are confused, feel complicated, scared, and uncomfortable. The originator constructs in this study were: (1) confusing, (2) complicated, (3) scary, (4) uncomfortable, (5) lack of accounting implementation, (6) transparency, (7) good governance, (8) well managed, and (9) responsibility to investors. Because of the lack of accounting knowledge (originator construct), startup companies are confused, complicated, scary, and uncomfortable, so companies are less of accounting implementation. This situation, however, is not good for governance, transparency, management, and responsibility for investors. As a result, there will be difficulties measuring growth, difficulty surviving and achieving their wealth goals (destination constructs).

The thirteen constructs identified from the ZMET process of this study can be categorized into three main themes, namely: (1) mental blocking of accounting, (2) accounting as a tool, and (3) Startup ultimate goal. Grouping the twelve consensus map constructs into the three main themes is shown in table 2. Each theme is discussed further in the discussion section.

\section{ANALYSIS AND DISCUSSION}

The results of this study find four main themes that describe the perception of startup companies towards accounting:

\section{Mental Blocking of Accounting}

The seven participants chose images that represented negative constructs of accounting. Participants feel "scared," "confused," "uncomfortable" when they have to deal with accounting. These feelings are mental blocking of accounting. A mental block is a mental or psychological

Figure 1.

Consensus Map of Participants

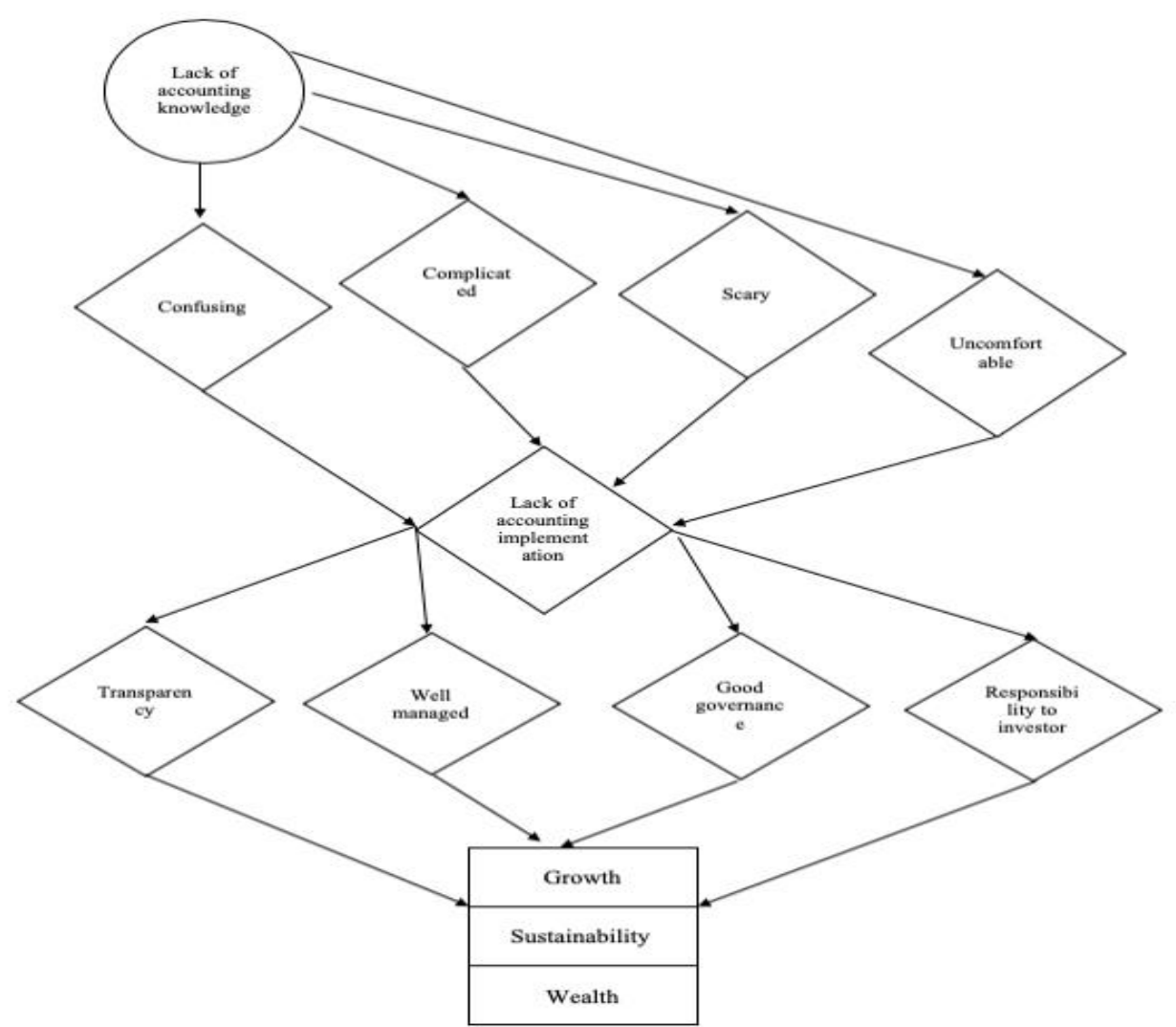


barrier that covers one's mind. It can arise from life experiences or association mistakes, past traumatic remnants, the rest of the inner wounds, the rest of unpleasant experiences when small, or because of "mistakes" or inaccuracies in the perspective/presumption of something even due to inappropriate learning/ education methods. Its appearance (manifestation) can be in the form of awkwardness in action, difficulty speaking (especially in public), difficulty actualizing yourself (although it has various advantages, such as intelligence/other abilities), sometimes also appearing in the form of "inferior complex" syndrome.

In the case of startup companies towards accounting, the cause is a lack of knowledge of the founders/co-founders regarding accounting matters. All founders/co-founders who are participants of this study do not have adequate background accounting; even 6 participants have no background related to the economy or business. The lack of knowledge about accounting makes them trapped in the inaccuracy of perspective due to mental blocking. As a result, they cannot implement accounting appropriately. This finding is in line with

Table 2.

Categorization of Consensus Map Constructs in the Main Themes

Consensus Map
Construct

Confusing

Complicated

Scary

Uncomfortable

Lack of accounting

knowledge

Mental blocking of accounting

Less of accounting implementation

\begin{tabular}{lc}
\hline $\begin{array}{l}\text { Transparency } \\
\text { Good governance }\end{array}$ & Accounting as \\
toll managed & \\
$\begin{array}{l}\text { Responsibility to } \\
\text { investor }\end{array}$ & \\
\hline $\begin{array}{l}\text { Growth } \\
\text { Sustainability } \\
\text { Wealth }\end{array}$ & $\begin{array}{c}\text { Startup ultimate } \\
\text { goal }\end{array}$ \\
\hline
\end{tabular}

San Juan (2007). San Juan (2007) stated that it is very difficult to introduce accounting to young adults since they develop a mental block in understanding accounting concepts; even many college students majoring in accounting have this kind of mental block.

\section{Accounting as Tool}

Although startup companies are trapped in the negative stigma of accounting, they consider accounting as a tool to achieve their goals. They believe that the accounting system enables them to create good governance, provide transparency to each party as a responsible media for their investor; thus, a startup will remain well managed. Instead of traditional/standard accounting, which they cannot implement well, they use different accounting. All startup companies in this research used innovation accounting. Innovation accounting is the best tool to capture startup performance (Ries, 2011).

McClure (2008) stated five stages of measurement in innovation accounting; acquisition, activation, retention, revenue, and referral. Five from seven startup participants have started to measure using McClure's. McClure's model combines quantitative and qualitative measurement. This measurement reports the existing situation precisely and is also good to capture the growth and predict the future.

Although McClure has emphasized the mixture combination, most participants still cannot combine quantitative and qualitative measurements in practice. "We don't know how to start" is the common

Figure 2.

McClure’s Pirate Metrics (Source: McClure, 2008)

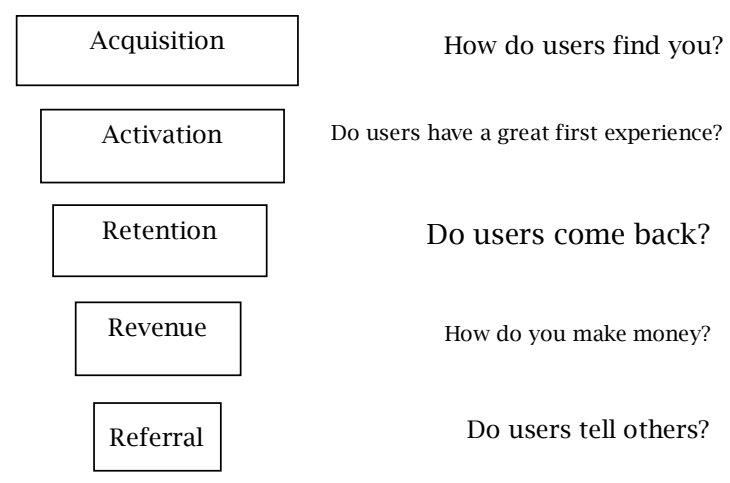


sentence for most participants. This fact is undeniably challenging. Groenewegen \& De Langen (2012) found that many startups cannot maintain their sustainability because they cannot do correct measurements and implement less accounting.

\section{The Ultimate Goal of The Startup}

Four startups in Indonesia have "unicorn" status. They are Go-Jek, Tokopedia, Traveloka, and Bukalapak. Unicorn is the status given to a startup with a valuation of more than US $\$ 1$ billion. The success of those four startups inspires other startups in Indonesia. Their goal is to become a unicorn. To be a unicorn, they have to maintain a good accounting system. They realize that sooner or later, they have to refine their accounting system whether they like it or not. In the first three to five years, usually, startups do not get any profit yet (Soto, 2015). However, their revenue can be boosted exponentially after the market is fit. Startup companies should utilize the first five years to start a good accounting system. Therefore, they can boost their income, maintain the sustainability of the business, and, like one of the participants said, become "young and rich".

Brem (2008), Nandram \& Boemans (2001), Rauch (2000), and Ries (2011) stated that startups have a good concept and future insight but lack organizational and entrepreneurial skills. Startups also have homework on the thorough business plan, clear strategy/mark analysis/ competitor analyses and aggressive competitor strategy, innovation as a business idea, and being a member of a formal network having an advisory board and active marketing. Their wealth or unicorn goal cannot be met if they do not fix their accounting system. They may perceive accounting as a ladder for their ultimate goal, but if they cannot move "the scary Freddy" out of their head, then it would be nonsense.

\section{CONCLUSION}

The results of this study explain in-depth the views of startup companies on accounting. By using the ZMET method, this study explores and identifies 13 important constructs that explain three main themes: mental blocking of accounting, accounting as a tool, and ultimate startup goals. In this study, accounting is seen as terrible, difficult, confusing, and uncomfortable for startup companies. This is due to the lack of accounting knowledge of these startup founders/co-founders. Because of the "mental blocking", eventually startups lack in accounting implementation. They assume that accounting will make their company better governed, well managed, transparent. In other words, accounting is their tool if they want to achieve their ultimate goal.

This finding brings several implications, especially improvement efforts, such as building a more userfriendly accounting system for startups who consider accounting to be terrible. In addition, startups need to collaborate with universities that have accounting programs for accounting assistance programs. Founders and co-founders of startups usually at a young age; accounting students and startups are expected to communicate better at the same young age.

\section{LIMITATIONS AND SUGGESTIONS.}

The limitation of this study lies in the low generalizability of the results of the study. It is due to the limited context and participants of the study. However, exploration with the ZMET method does involve a limited context but with deep exploration. Therefore, further research can explore the perceptions of startup companies in different contexts, for example, management accounting or taxation.

\section{REFERENCES}

Brem, A. (2008). The boundaries of innovation and entrepreneurship. Wiesbaden: Erlangen Nürnberg.

Coulter, R.A, Zaltman, G., \& Coulter, K.S. (2001). Interpreting consumer perceptions of advertising: An application of the Zaltman Metaphor Elicitation Technique. Journal of Advertising, 30(4), 1-21. 
Coulter, R. (2006), "Consumption experiences as escape: an application of the Zaltman Metaphor Elicitation Technique", in Belk, R, (Ed.), Handbook of Qualitative Research Methods in Marketing, Edward Elgar, Cheltenham, pp. 400-418.

Croll, A., \& Yozkovitz, B. (2013). Lean analytics: Use data to build a better startup faster. CA: O Reilly Media Inc.

Danilet, Ma., \& Bobalca, C.S. (2017). Using ZMET for investigating the role of social media in the employment process. Review of Economic \& Business Studies, 10(1), 9-32.

De Mel, S., McKenzie, D., \& Woodruff, C. (2014). Business training and female enterprise start-up, growth, and dynamics: Experimental evidence from Sri Lanka. Journal of Development Economics, 106(C), 199-210.

Groenewegen, G., \& De Langen, F. (2012). Critical success factors of the survival of start-ups with a radical innovation. Journal of Applied Economics and Business Research, 2 (3): 155-171.

Hancock, C., \& Foster, C. (2019). Exploring the ZMET methodology in services marketing. Journal of Services Marketing 34(1), 48-58.

Kasali, R. (2018). The great shifting. Jakarta: Gramedia Pustaka Utama Indonesia.

Khoo-Lattimore, C., Thyne, M., \& Robertson, K. (2009). The ZMET method: Using projective technique to understand consumer home choice. The Marketing Review, 9(2), 139-154.

McClure. (2008). Startup Metrics for Pirates. London: Seed Camp University.

Nandram, S.S., \& Boemans, M. (2001). De beste ondernemer: Condities voor ondernemerssucces. Breukelen: Universiteit Nyenrode.

Puspasari, N., Herwiyanti, E., \& Pinasti, M. (2021), Barking up the wrong tree: SMEs' perception of tax using the ZMET Method. Journal of Economics and Business, 4(1), 147-156.

Rauch, A. (2000). Success factors of small and medium sized enterprises. Amsterdam: Universiteit van Amsterdam.

Ries, E. (2011). The lean startup: How today's entrepreneurs use continuous innovation to create radically successful businesses. New York: Crown Business.

San Juan-Donatila Agtarap. (2007). Fundamentals of accounting fundamentals of accounting: Basic accounting principles simplified for accounting students. USA: AuthorHouse.

Soto, E. (2015). Innovation accounting methods to assure validated learning: The case of Finnish startups. Turku University of Applied Sciences.

Zaltman, G. (1996). Metaphorically speaking: New technique uses multidisciplinary ideas to improve qualitative research. Marketing Research, 8(2), 13-20.

Zaltman, G. (1997). Rethinking market research: Putting people back in. Journal of Marketing Research,34(4), 424-437.

Zaltman, G., \& Coulter, R.H. (1995). Seeing the voice of the customer: Metaphorbased advertising research. Journal of Advertising Research, 35(4), 35-51.

Internet References:

https://www.startupranking.com

Drobotdean. (2019). Potrait of a confused african man. Retrieved from https:// www.freepik.com

Bedneyimages. (2016). Whiteboard with formulas. Retrieved from https:// www.freepik.com

Gpointstudio. (2021). Man checking time on his watch. Retrieved from https:// www.freepik.com

Jcomp. (2018). Happy man with cash dollars flying in home office, rich from business online concept. Retrieved from https://www.freepik.com

https://flickr.com 